\title{
O Registo Oncológico Regional Sul e a Investigação Clinica em Portugal: Desafios e Oportunidades
}

\author{
Regional Cancer Registry and Clinical Research in Portugal: Challenges \\ and Opportunities
}

Joana RIBEIRO ${ }^{1}$, Fátima CARDOSO ${ }^{1}$

Acta Med Port 2014 May-Jun;27(3):282-283

Palavras-chave: Neoplasias; Registos; Portugal.

Keywords: Neoplasms; Registries; Portugal.

O estudo publicado nesta edição da Acta Médica Portuguesa por Rosário André et al sob o título "Breast Cancer Patients Survival and Associated Factors: Reported Outcomes from the Southern Cancer Registry in Portugal"1 representa um bom exemplo da forma como os registos oncológicos podem tornar-se plataformas de excelência para o desenvolvimento da investigação clinica, nomeadamente na área de 'outcomes research'.

Neste trabalho, os autores tinham como objectivo analisar as variações epidemiológicas de padrão de tratamento e de sobrevida de acordo com a região geográfica no Sul do Pais e Região Autónoma da Madeira (RAM). Procederam à análise retrospectiva dos casos de cancro da mama diagnosticados em 2005 nestas regiões através da base de dados do Registo Oncológico Regional Sul (ROR-Sul). Foram avaliados 1354 doentes, maioritariamente da região de Lisboa e Vale do Tejo (67\%), apresentando a população uma média de idade de 61 anos, com cancros da mama cuja morfologia mais frequente foi carcinoma ductal invasivo (82,8\%), estádio I e II (68\%). Biologicamente, os tumores identificados foram, na sua maioria, do tipo luminal (receptores hormonais positivos) (64\%), apresentando sobre-expressão do gene HER-2 em $23 \%$ dos casos. Como expectável, a sobrevida global está significativamente associada com o estádio e o subgrupo biológico da doença. $O$ dado mais significativo foi a ausência de diferença nas taxas de sobrevida de acordo com a região do país, um dos objectivos principais do estudo. Os autores sugerem como causa mais provável para este resultado o facto de a grande maioria dos doentes pertenceram à região Lisboa/Vale do Tejo, com pouca representação das restantes regiões.

Este trabalho expõe e permite identificar alguns dos desafios com que o registo oncológico regional do sul, em particular, e outros programas de registo médico, em geral, se deparam. Estes relacionam-se, por exemplo, com a acuidade da colheita dos dados clínicos e a sua integridade, e com o intervalo de tempo que frequentemente decorre entre o ano do diagnóstico e a análise/publicação dos resultados.

O presente artigo baseia-se em dados de 2005 , repre-

sentando um intervalo de tempo entre o ano do diagnóstico e a publicação dos dados de aproximadamente nove anos. Este atraso substancial na comunicação/publicação dos resultados, particularmente numa área onde o progresso ocorre a um ritmo acelerado, torna impossível obter uma imagem em tempo real do padrão de tratamento do cancro da mama, o que por sua vez torna difícil não só a adopção e a implementação de estratégias que melhorem os cuidados de saúde prestados, mas também a avaliação (além da retrospectiva) dos efeitos da alteração/mudança dos padrões de tratamento nos resultados médicos a médio e longo prazo.

Outro desafio com que se deparam os registos oncológicos é a necessidade da adopção de medidas que permitam garantir a integridade dos dados e o acompanhamento/ evolução dos mesmos ao longo do tempo, especialmente na ausência de processos clínicos electrónicos ou de pelo menos um processo clinico único em cada instituição.

Embora em 2005 tenham sido registados no ROR-Sul 2 821 novos casos de cancro de mama, a análise final deste trabalho baseia-se em 1354 (48\%) casos. Por outro lado, alguma informação indispensável para a caracterização desta doença na actualidade, como o status dos receptores hormonais ou do gene HER-2, não se encontra disponível em $13 \%$ e $24 \%$ dos casos, respectivamente. O reconhecimento do deficit generalizado dos registos médicos e a dificuldade de extracção de informação dos mesmos podem ser algumas das explicações para esta escassez de informação. A passagem progressiva para processos electrónicos baseados em dados categorizáveis (e não em texto livre como a maioria dos implementados neste momento) e o desenvolvimento de bases de dados nas diferentes instituições com estruturas similares e compatíveis com a base do ROR são potenciais soluções que necessitam de uma acção concertada de todos os envolvidos.

O cancro continua a constituir um problema de saúde major para o qual é necessária a adopção de diversas intervenções, cuja monitorização e avaliação depende da disponibilidade de dados robustos. Há vários anos que as Sociedades científicas reconheceram a importância e o

1. Unidade de Mama. Centro Clínico Champalimaud. Lisboa. Portugal.

Recebido: 15 de Junho de 2014 - Aceite: 16 de Junho de 2014 | Copyright @ Ordem dos Médicos 2014 
papel fundamental dos registos populacionais nos planos de prevenção e controlo das doenças oncológicas. Os registos oncológicos podem também fornecer uma amostra de população adequada para o desenvolvimento de alguns estudos clínicos, nomeadamente epidemiológicos e de avaliação do efeito da aplicação de novos tratamentos e/ ou novas estratégias (ex: efeito da abordagem multidisciplinar).

Para que todas estas possibilidades possam ser realizáveis é necessário apoiar os registos oncológicos, possibilitando uma melhoria da qualidade e profundidade dos dados recolhidos, uma actualização mais frequente dos mesmos, e, finalmente, uma cobertura mais ampla do ter-

\section{REFERÊNCIAS}

1. André MR, Amaral S, Mayer A, Miranda A. Breast cancer patients survival and associated factors: reported outcomes from the Southern ritório representado. As estruturas devem ser dotadas dos recursos humanos, materiais e financeiros adequados.

Quando todos estes requisitos tiverem sido alcançados poderemos talvez contar com um registo oncológico que, expandindo a sua área de intervenção além do papel tradicional de colecção de dados, se torne uma ferramenta central no apoio não só aos decisores políticos, permitindo a tomada de decisões informadas nas áreas de controlo do cancro, mas também à comunidade médica/cientifica proporcionando uma ferramenta através da qual investigação clinica e translacional com qualidade possa ser desenvolvida. 


\section{O Registo Oncológico Regional Sul e a Investigação Clinica em Portugal: Desafios e Oportunidades \\ Acta Med Port 2014:27:282-283}

Publicado pela Acta Médica Portuguesa, a Revista Científica da Ordem dos Médicos

Av. Almirante Gago Coutinho, 151

1749-084 Lisboa, Portugal.

Tel: +351 218428215

E-mail: submissao@actamedicaportuguesa.com

www.actamedicaportuguesa.com

ISSN:0870-399X | e-ISSN: 1646-0758

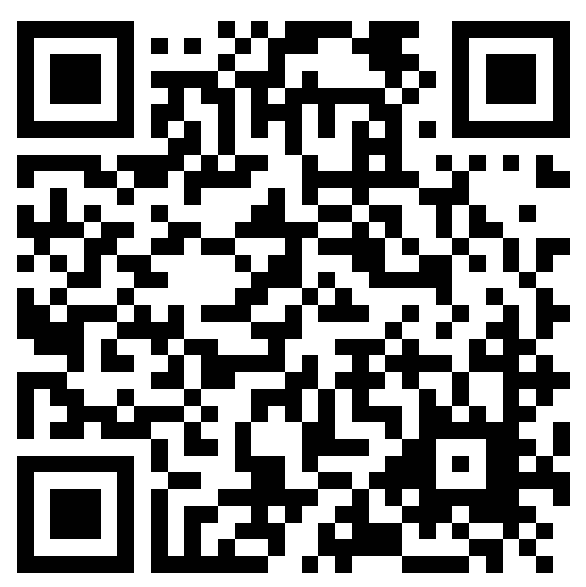

